\title{
Cultivation of cassava and cowpea in intercropping systems held in Roraima's savannah, Brazil ${ }^{1}$
}

\author{
Consórcio de mandioca com feijão-caupi cultivados na savana de Roraima
}

\author{
José de Anchieta Alves de Albuquerque ${ }^{2}$, Larissa Souza de Campos Oliva ${ }^{3}$, José Maria Arcanjo Alves ${ }^{2}$, Sandra \\ Catia Pereira Uchôa ${ }^{4 *}$ e Djair Alves de Melo ${ }^{5}$
}

\begin{abstract}
The objective of this work was to assess the cultivation of cassava and cowpea in different systems and arrangements of plants in Roraima's savannah, Brazil. The experiment was performed at the experimental field of the Department of Soil and Climate at the UFRR, Boa Vista (Roraima). The experimental design adopted was in randomized blocks, with seven treatments and four replications. The treatments were: 1) a single row of cassava in monoculture; 2) a single row of cassava plus a row of cowpea; 3 ) a double row of cassava in monoculture; 4) a double row of cassava plus a row of cowpea; 5) a double row of cassava plus two rows of cowpea; 6 ) a double row of cassava plus three rows of cowpea; and 7) cowpea in monoculture. For the cassava were assessed the following variables: yield of roots, fresh weight of shoot, harvest index, number of roots per plant, roots length, roots diameter, root dry matter, starch content and index of area equivalence. For the cowpea were assessed: yield of the grains $\left(\mathrm{kg} \mathrm{ha}^{-1}\right)$, number of pods per plant, number of seeds per pod, weight of 1000 seeds, and index of area equivalence. The double rows cropping systems of cassava with two and three rows of cowpea allow obtaining equivalent yield to the monoculture of cassava in single rows. The intercropping, regardless of the arrangement, reduces grain yield of cowpea. All treatments in intercropping systems exhibit a satisfactory area equivalence index, with an average of 1.55.
\end{abstract}

Key words: Manihot esculenta Crantz. Vigna unguiculata (L.) Walp. Area equivalent index. Single and double rows.

RESUMO - Objetivou-se com este trabalho avaliar o consórcio de mandioca com feijão-caupi, cultivados na savana de Roraima. O experimento foi realizado no campo experimental do Departamento de Fitotecnia da UFRR, Boa Vista-Roraima. O delineamento experimental adotado foi em blocos casualizados, com sete tratamentos e quatro repetições. Os tratamentos foram: 1) fileira simples da mandioca em monocultivo; 2) fileira simples de mandioca mais uma linha de feijão-caupi; 3) fileira dupla de mandioca em monocultivo; 4) fileira dupla de mandioca mais uma linha de feijão-caupi; 5) fileira dupla de mandioca mais duas linhas de feijão-caupi; 6) fileira dupla de mandioca mais três linhas de feijão-caupi, e 7) feijão-caupi em monocultivo. Na mandioca foram avaliadas: produção de raízes, massa fresca da parte aérea, índice de colheita, número de raízes por plantas, comprimento de raízes, diâmetro de raízes, matéria seca de raízes, teor de amido e índice de equivalência de área. No feijão-caupi avaliaram-se: produtividade de grãos $\left(\mathrm{kg} \mathrm{ha}^{-1}\right)$, número de vagens por planta, número de sementes por vagem e massa de 1.000 sementes e índice de equivalência de área. Os sistemas de cultivos em fileiras duplas de mandioca com duas e três linhas de feijão-caupi permitiram obter produções equivalentes ao monocultivo de mandioca em fileiras simples. A produtividade de grãos do feijão-caupi em fileira simples (monocultivo) foram superiores aos tratamentos consorciados. Todos os tratamentos em sistemas de cultivos consorciados apresentaram índice de equivalência de área satisfatório, com média de 1,55.

Palavras-chave: Manihot esculenta Crantz. Vigna unguiculata (L.) Walp. Índice de equivalência de área. Fileira simples e dupla.

\footnotetext{
DOI: $10.5935 / 1806-6690.20150018$

*Autor para correspondência

${ }^{1}$ Recebido para publicação em 10/10/2013; aprovado em 21/12/2014

Pesquisa financiada pelo $\mathrm{CNPq}$

${ }^{2}$ Departamento de Fitotecnia of CCA/UFRR, BR 174, km 12, s/n, Campus do Cauamé, Boa Vista-RR, Brazil, 69.310-270, anchietaufrr@ gmail.com, arcanjoalves@oi.com.br

${ }^{3}$ Agronomy Course, BR 174, km 12, s/n, Campus do Cauamé, Boa Vista-RR, Brazil, 69.310-270, larisseoliva@yahoo.com.br

${ }^{4}$ Departamento de Solos e Engenharia Agrícola of CCA/UFRR, BR 174, km 12, s/n, Campus do Cauamé, Boa Vista-RR, Brazil, 69.310-270. sandra.uchoa@ufrr.br

${ }^{5}$ Instituto Federal de Educação, Ciência e Tecnologia de Roraima, Campus Novo Paraíso, Caracaraí-RR, Brazil, 69.300-000, djairmelo@ifrr.edu.br
} 


\section{INTRODUCTION}

Cassava has a wide adaptation to different soil and climatic conditions being grown in Brazil since the states of Roraima to Rio Grande do Sul (ALBUQUERQUE et al., 2014). In Roraima, cassava is the more traditional culture, being cultivated on 6,210 ha, mainly by small farmers, involving monoculture and intercropping with cowpea (ALVES et al., 2009), with an average yield of $13.5 \mathrm{t} \mathrm{ha}^{-1}$ (INSTITUTO BRASILEIRO DE GEOGRAFIA E ESTATÍSTICA, 2014). Considering the cost of cassava yield, it is believed that a significant portion is due to weed control; however, this value depends on several factors, including the plantation system (ALBUQUERQUE et al., 2008).

The intercropping is interesting in relation to sole cropping, for several reasons: intensive use of the area, vegetative soil protection against erosion and improvement of weed control. The disadvantages are due to the increase of skilled labor and competition between the species (BAUMANN; BASTIAANS; KROPFF, 2001). According to Alves et al. (2009) in the intercrops occur reduction of the incidence of pests and diseases, providing, with greater frequency, greater profits for small farmers, besides diversifying the sources of income and food. Because of the few studies on this subject, therefore, in the scientific area, occurs the challenging of information about results found in intercropping systems and spatial arrangements. Flesch (2002) states that intercropping provides more agronomic and economic advantages than the sole crops. Albuquerque et al. (2012) state that usually the yield in sole culture is superior to intercropping.

The planting of beans intercropped with other crops is common practice in Brazil, being carried out mainly by small farmers (ANDRADE et al., 2001). In Minas Gerais State, for exemplo, it is estimated that about $60 \%$ of the crop of beans are associated with corn and other crops (COSTA; SILVA, 2008). The intercropping cassava and cowpea (bean) is possible due to the relatively wide spacing between rows of cassava, the lower speed of cassava settling and forming the canopy, the relatively short cycle and obtaining of cowpea crop, besides the contribution to the supply of organic matter and nitrogen to the soil (DEVIDE et al., 2009), as well as the protection of the soil. According to Martinotto et al. (2012) the species in the initial growth phase, in intercropping, do not alter the fresh weight yield of cassava shoot.

In cassava crops, planting can be done with plants arranged in single rows and double rows (SCHONS et al., 2009). According to Albuquerque et al. (2012) in monocropping of cassava no difference in root yield was observed when grown in rows single or double. The double rows, associated to the intercropping, reduce the area available for the weeds.
Results showed that the losses in the productivity of roots in the culture caused by the competition of weeds, in extreme situations, were quite significative, almost 100\% (JOHANNS; CONTIERO, 2006). There is controversy in the literature on the yield gain as to the use of double rows in sole crop or intercropped (GABRIEL FILHO; STROHHAECKER; FEY, 2003). Considering these aspects, the research has been using more often an index that assesses the efficiency of intercropping systems, based on acreage (MATTOS et al., 2005a, 2005b).

Studies on the combinations of the spatial distribution of plants in the canopy seeking to maximize biological and economic yield in both sole cropping and intercropping system, are relevant, given the availability of new cultivar processes (ALBUQUERQUE et al., 2012).

The objective of this work was to assess the cultivation of cassava and cowpea (Vinga unguiculata (L.) Walp.) in different systems and arrangements of plants in conditions of the Roraima's savannah, Brazil.

\section{MATERIAL AND METHODS}

\section{Experiment location}

The experiment was installed, at beginning of the rainy season, in a dystrophic cohesive Yellow Latosol, located in the Cauamé Campus, of the Centro de Ciências Agrárias (Center for Agricultural Sciences) of the Universidade Federal de Roraima, in the Boa Vista city, Roraima State, Brazil (Latitude 2' 52' 20,7'”N, Longitude 60 42' 44,2”, mean altitude of $90 \mathrm{~m}$ ). According to Köppen classification, the climate corresponds to the Aw category, with two e well-defined climate seasons, a rainy season (April-August) and a dry season (Octuber-March). The results of the chemical and physical attributes of the local soil of the experiment are shown in Table 1.

The data relating to rainfall $(\mathrm{mm})$, relative humidity of the air $(\%)$ and mean temperature $\left({ }^{\circ} \mathrm{C}\right)$, in the period in which the experiment was conducted, are presented in Figure 1.

\section{Experimental design and treatments}

The experimental design adopted was in randomized blocks, with seven treatments and four replications. The treatments consisted of crops of cassava and cowpea planted in intercropping and monoculture, as shown in Table 2.

The plots consisted of $6.0 \mathrm{~m}$ long by $6.0 \mathrm{~m}$ wide, totaling $36 \mathrm{~m}^{2}$. The soil area was formed by the two central rows, eliminating $1.0 \mathrm{~m}$ at each end as front borders, with a soil area of $8 \mathrm{~m}^{2}$ for $\mathrm{T} 1$ and $\mathrm{T} 2 ; 10 \mathrm{~m}^{2}$ for $\mathrm{T} 3, \mathrm{~T} 4, \mathrm{~T} 5$ 
Table 1 - Chemical and physical attributes of two depths 0-20 and 20-40 cm of the dystrophic cohesive Yellow Latosol soil of the experimental area ${ }^{1 /}$

\begin{tabular}{|c|c|c|c|c|c|c|c|c|c|c|}
\hline \multirow{2}{*}{ Layer } & \multirow{2}{*}{$\mathrm{pH} \mathrm{H} \mathrm{H}_{2} \mathrm{O}$} & $\mathrm{P}^{2 /}$ & $\mathrm{K}^{2 \prime}$ & $\mathrm{Ca}^{3 /}$ & $\mathrm{Mg}^{3 /}$ & $\mathrm{Al}^{3 /}$ & $\mathrm{H}+\mathrm{Al}^{4 /}$ & $\mathrm{ECEC}^{5 /}$ & $\mathrm{BS}^{6 /}$ & O.M ${ }^{7 /}$ \\
\hline & & $\mathrm{mg} \mathrm{dm}{ }^{-3}$ & \multicolumn{6}{|c|}{ - } & $(\%)$ & $\mathrm{g} \mathrm{kg}^{-1}$ \\
\hline $0-20$ & 5.16 & 0.6 & 62 & 0.84 & 0.10 & 0.20 & 1 & 2.16 & 53.9 & 6.1 \\
\hline $20-40$ & 5.06 & 0.5 & 70 & 0.24 & 0.03 & 0.51 & 1.2 & 1.65 & 27.3 & 4.0 \\
\hline Layer & Thick sand & Fine sand & Silt & Clay & \multicolumn{6}{|c|}{ Textural Class } \\
\hline \multicolumn{11}{|c|}{ - } \\
\hline $0-20$ & 400 & 300 & 70 & 220 & \multicolumn{6}{|c|}{ Franco-Clay-Sandy } \\
\hline $20-40$ & 360 & 290 & 90 & 260 & \multicolumn{6}{|c|}{ Franco-Clay-Sandy } \\
\hline
\end{tabular}

${ }^{1}$ Analysis performed at the Laboratory of Soils of UFV; ${ }^{2 /}$ Available $\mathrm{P}$ and $\mathrm{K}$ - Mehlich Extractor $-1 ;{ }^{3 /}$ Extractor $\mathrm{KCl} 1 \mathrm{~mol} \mathrm{~L} \mathrm{~L}^{-1}{ }^{4 /} \mathrm{Extractor} \mathrm{Ca}(\mathrm{OAC})_{2}$ $0.5 \mathrm{~mol} \mathrm{~L}^{-1}, \mathrm{pH} 7.0 ;{ }^{5 /} \mathrm{ECEC}$ - Total cation exchange capacity - obtained by summation of the exchangeable cations and potencial acidity $(\mathrm{K}, \mathrm{Ca}, \mathrm{Mg}$, $\mathrm{H}+\mathrm{Al}$ ), Base saturation (\%); ${ }^{6 /}$ Organic Matter - derived by multiplying Organic carbon (determined by Walkey-Black method) by factor 1.72

Figure 1 - Rainfall $(\mathrm{mm})$, average temperature $\left({ }^{\circ} \mathrm{C}\right)$ and relative humidity of the air (\%) during the period of performance of the experiment. Data obtained from the meteorological station of the Department of Soils and Agricultural Engineering of the CCA-UFRR. Boa Vista, Roraima state 2012

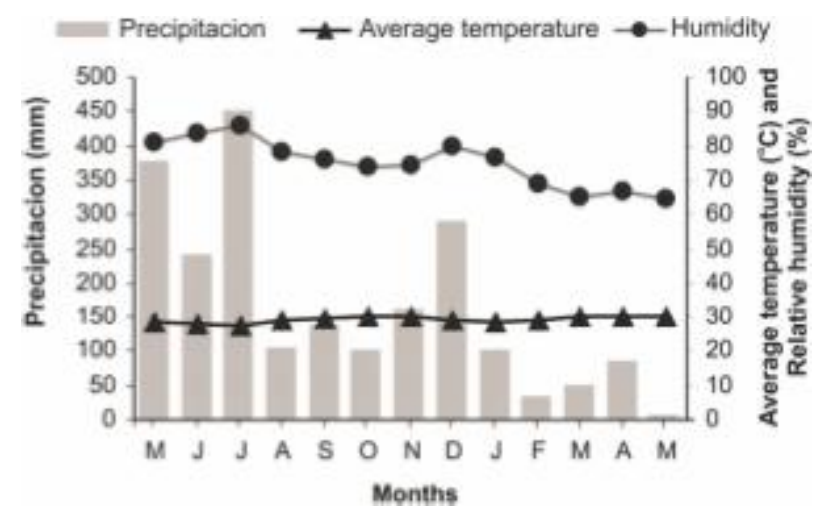

and $\mathrm{T} 6$, in the latter, the three central rows of the culture of cowpea were considered, and $4 \mathrm{~m}^{2}$ for treatment $\mathrm{T} 7$.

\section{Experiment conduction}

At the stage of tillage, plowing and harrowing were held, proceeding to liming (1 $\mathrm{t} \mathrm{ha}^{-1}$ dolomitic limestone) and fertilization $\left(\mathrm{N}-30 \mathrm{~kg} \mathrm{ha}{ }^{-1}\right.$, urea source; $\mathrm{P}_{2} \mathrm{O}_{5}-90 \mathrm{~kg}$ $\mathrm{ha}^{-1}$, triple superphosphate source; and $\mathrm{K}_{2} \mathrm{O}-60 \mathrm{~kg} \mathrm{ha}^{-1}$, potassium chloride source). The cassava cultivar used was Aciolina, being the most planted in the State of Roraima because it presents the best set of desirable characteristics for both fresh consumption and for the industry, justifying is intense cultivation and marketing (ALVES et al., 2009; OLIVEIRA et al., 2011; OLIVEIRA et al., 2012). The cultivar of cowpea was UFRR grão verde due to high yield and good adaptability to the intercropping with cassava, as evidenced by Alves et al. (2009).

The planting of cassava was held simultaneously with cowpea on May 15, 2008. The cuttings-seeds

Table 2 - Description of the seven treatments with their respective spacings

\begin{tabular}{lcc}
\hline Treatment & Description & Spacing $(\mathrm{m})$ \\
\hline T1 & Single row of cassava + 1 row of cowpea between rows of cassava & $(1.0 \times 0.5)$ \\
\hline T2 & Double row of cassava in monoculture & $(1.0 \times 0.5)$ \\
\hline T3 & Double row of cassava + 1 row of cowpea between double rows of cassava & $(2.0 \times 0.5 \times 0.5)$ \\
T4 & Double row of cassava +2 rows of cowpea between double rows of cassava & $(2.0 \times 0.5 \times 0.5)$ \\
T5 & Double row of cassava +3 rows of cowpea between double rows of cassava & $(0.75 \mathrm{~m}$ among rows $)$ \\
\hline T6 & & $(0,50 \mathrm{~m}$ among rows $)$ \\
\hline T7 & Single row of cowpea in monoculture & $(0.50 \mathrm{~m}$ among rows $)$ \\
\hline
\end{tabular}


were $25 \mathrm{~cm}$ long, planted horizontally in furrows $10 \mathrm{~cm}$ deep, with spacings as described in Table 2.

\section{Determination of yield and yield components}

The cassava harvest was performed at 12 months after planting, on May 20, 2009, and the characteristics assessed were: number of roots per plant, root length and diameter $(\mathrm{cm})$, root yield $\left(\mathrm{kg} \mathrm{ha}^{-1}\right)$, fresh weight of shoot $\left(\mathrm{kg} \mathrm{ha}^{-1}\right)$, root dry matter $(\%)$, starch content $(\%)$ and harvest index. The dry matter and starch content were determined by the method of hydrostatic balance (GROSSMANN; FREITAS, 1950) and the harvest index (HI) using the formula: IC = (fresh weight of the roots)/ (plant total fresh weight) x 100.

Planting was performed in furrows spaced $0.5 \mathrm{~m}$, at a depth of 3-5 cm, with eight seeds per meter. The harvest of cowpea was performed in four times, between 50 and 57 days after planting (June 15 to 22, 2008). The following characteristics were assessed: yield of the grains $\left(\mathrm{kg} \mathrm{ha}^{-1}\right)$, number of pods per plant, number of seeds per pod and weight of 1,000 seeds $(\mathrm{g})$.

For the intercropping treatments was determined the Equivalence index of area (EIA), using the formula: EIA = (intercropping cassava yield $\div$ monoculture cassava yield) + (intercropping cowpea yield $\div$ monoculture cowpea yield).

\section{Statistical analyses}

Statistical analysis was performed separately for the two cultures. The results were submitted to analysis of variance using the $\mathrm{F}$ test at $5 \%$ probability and the averages compared by the test of Tukey at $5 \%$ probability.

\section{RESULTS AND DISCUSSION}

Summaries of analyses of variance for the assessment of different systems and arrangements of cultivation of cassava and cowpea, of the variables related to cassava and cowpea culture are presented in Tables 3 and 4. Only for root yield $\left(\mathrm{kg} \mathrm{ha}^{-1}\right)$ there was statistical difference between their averages (Table 3). In works performed by Albuquerque et al. (2012) in the city of Coimbra, Minas Gerais state, at the experimental campus of UFV, where yield components were assessed in various spacial arrangements between ordinary beans and cassava and verified that in fresh weight of shoot, harvest index, root length, root dry matter and starch content characters were not found significant differences between their treatments.

Related to the characteristics of the cowpea, the average of the treatments of the weight of 1,000 seeds and number of seeds per pod did not differ statistically among themselves (Table 4). According to these results, it can be inferred that the behavior of the cassava culture did not affect cowpea in these characteristics. As for the characteristics number of pods per plant, pod length and grain yield there was a statistical difference between their averages, i.e., the intercropping treatments affected the culture of cowpea in these characteristics. Similar results regarding the negative effect of the intercropping in the yield of beans were observed by Albuquerque et al. (2012) in Yellow-Red Argissol in Minas Gerais state, Brazil.

The Table 5 presents the averages of the variables assessed in culture cassava. The fresh weight of shoot, number of roots per plant, root length, root dry matter, starch content of the roots and harvest index did not differ statistically among themselves. Statistical difference was observed for the variables diameter of the root and yield, which infers that the arrangements of the cassava and cowpea intercropping did not affect these characteristics.

For the characteristic fresh weight of shoot, the average of its treatments was $14,738 \mathrm{~kg} \mathrm{ha}^{-1}$ (Table 5). The foliage yield is an important factor in the cassava culture for it is related to the yield of material for spreading and to the use

Table 3 - Summary of analysis of variance of the data regarding the yield of roots (YIELD - $\left.\mathrm{kg} \mathrm{ha}^{-1}\right)$, fresh weight of shoot $\left(\mathrm{FW}-\mathrm{kg} \mathrm{ha}^{-1}\right)$, harvest index (HI - \%), number of roots per plant (NRP), root length (RL - cm), roots diameter (RD - cm), roots dry matter (RDM - \%) and starch content (SC - \%) of the cassava root of the cultivar "Aciolina” harvested at twelve months after planting. Boa Vista, Roraima state, 2012

\begin{tabular}{|c|c|c|c|c|c|c|c|c|c|}
\hline \multirow{2}{*}{ FV } & \multirow{2}{*}{ GL } & \multicolumn{8}{|c|}{ Average squares } \\
\hline & & YIELD & FW & $\mathrm{HI}$ & NRP & RL & $\mathrm{RD}$ & RDM & $\mathrm{SC}$ \\
\hline Blocks & 3 & $3,681,512$ & $1,774,896$ & 22.68 & 5.98 & 0.82 & 0.61 & 2.96 & 3.01 \\
\hline Treatments & 5 & $24,155,900 *$ & $1,401,205^{\text {ns }}$ & $60.63^{\mathrm{ns}}$ & $1.69^{\mathrm{ns}}$ & $10.94^{\mathrm{ns}}$ & $1.41 * *$ & $0.62^{\mathrm{ns}}$ & $0.62^{\mathrm{ns}}$ \\
\hline Residue & 15 & $2,726,216$ & $3,248,057$ & 20.45 & 0.98 & 9.45 & 0.24 & 0.47 & 0.48 \\
\hline Average & & 15.068 & 14.738 & 50.30 & 3.83 & 22.71 & 5.09 & 33.10 & 28.45 \\
\hline $\mathrm{CV}(\%)$ & & 10.96 & 12.23 & 8.91 & 25.85 & 13.54 & 9.70 & 2.08 & 2.42 \\
\hline
\end{tabular}

ns, **, * Not significant, Significant at $0.1 ; 1$ and $5 \%$ probability, respectively, by test $\mathrm{F}$ 
of the culture as fodder (VIDIGAL FILHO et al., 2000). The cassava shoot can be reused by the cassava farmers for feeding animals, being a good consumption alternative in the dry season (DANTAS et al., 2010). It is observed that the intercropped treatments did not interfere in the characteristics: fresh weight of shoot, number of roots per plant, roots length, roots dry matter, root starch content and harvest index (Table 5).

The average of the treatments of the harvest index characteristic was $50.30 \%$ (Table 5). According to Nonetheless, Cock and El-Sharkaway (1991) show that the optimal value for harvest index is between 50 and $65 \%$. Therefore, the average harvest index obtained was not negatively influenced by the arrangements of the intercropping between cassava and cowpea. Similar results of the intercropping of cassava with cowpea and corn were obtained by Devide et al. (2009).
The number of root per average plant was 3.83, which is within the limits shown in the literature. A cassava adult plant presents, in average, 3 to 12 roots per plant (ALBUQUERQUE et al., 2009).

The general average of the treatments of roots dry matter was of $33.10 \%$. According to Fukuda et al. (2006) the cassavas culture presents, on average, $30 \%$ of dry matter in the roots, although there are records of up to $45 \%$, and starch varies from 5 to $43 \%$.

The main characteristic that defines the quality of the cassava roots yield for the industry is the dry matter content. The dry matter content presents a direct correlation with the starch content (BORGES; FUKUDA; ROSSETTI, 2002), raw material extracted by starch factories, flour mills and manufacturers of cassava alcohol. The starch content corresponds to approximately $85 \%$ of the roots dry matter

Table 4 - Summaries of the analyses of variance of data on grain yield (YIELD - $\mathrm{kg} \mathrm{ha}^{-1}$ ), weight of 1,000 seeds (WS - $\mathrm{g}$ ), number of pod per plant (NPP), number of seeds per pod (NSP) and length of pod (LP) of cowpea, cultivar UFRR grão verde. Boa Vista, Roraima state, 2012

\begin{tabular}{lcccccc}
\hline \multirow{2}{*}{ FV } & GL & \multicolumn{5}{c}{ Average squares } \\
\cline { 3 - 7 } & & YIELD & WS & NPP & NSP & LP \\
\hline Blocks & 3 & 468.18 & 22.85 & 5.00 & 0.43 & 5.93 \\
Treatments & 5 & $97,052.93^{* * *}$ & $2.68^{\text {ns }}$ & $4.73 * * *$ & $2.33^{* *}$ & $0.49^{\text {ns }}$ \\
Residue & 12 & $1,415.73$ & 23.14 & 0.57 & 0.57 & 1.65 \\
Average & & 732.95 & 155.05 & 13.68 & 13.14 & 14.71 \\
CV $(\%)$ & & 5.13 & 3.10 & 5.50 & 5.76 & 8.73 \\
\hline
\end{tabular}

ns, ***,**,* Not significant, Significant at $0.1 ; 1$ and $5 \%$ probability, respectively, by test $\mathrm{F}$

Table 5 - Average values of fresh weight of shoot (FWS), number of roots per plant (NRP), root length (RL), root diameter (RD), root dry matter (RDM), roots starch content (RSC), roots yield (YIELD) and harvest index (HI), of cassava of the cultivar "Aciolina" in monoculture and intercropped with cowpea, harvested at 12 months after planting. Boa Vista, Roraima state, 2012

\begin{tabular}{lcccccccc}
\hline Treatment & FWS $\left(\mathrm{kg} \mathrm{ha}^{-1}\right)$ & NRP & RL $(\mathrm{cm})$ & RD $(\mathrm{cm})$ & RDM $(\%)$ & RSC $(\%)$ & YIELD (kg ha-1) & $\begin{array}{l}\text { HI } \\
(\%)\end{array}$ \\
\hline T1 & 15,746 & 4.95 & 20.50 & $3.90 \mathrm{~b}$ & 33.77 & 29.12 & $18,265 \mathrm{a}$ & 51.69 \\
T2 & 14,346 & 3.10 & 24.75 & $5.37 \mathrm{a}$ & 33.12 & 28.47 & $13,086 \mathrm{c}$ & 49.49 \\
T3 & 14,152 & 3.74 & 24.25 & $5.17 \mathrm{a}$ & 33.24 & 28.60 & $14,225 \mathrm{bc}$ & 50.41 \\
T4 & 15,125 & 4.12 & 23.25 & $5.30 \mathrm{a}$ & 32.63 & 27.98 & $11,900 \mathrm{c}$ & 49.60 \\
T5 & 14,572 & 3.45 & 22.00 & $5.47 \mathrm{a}$ & 32.97 & 28.32 & $17,322 \mathrm{ab}$ & 51.10 \\
T6 & 14,490 & 3.71 & 21.50 & $5.35 \mathrm{a}$ & 32.85 & 28.20 & $15,584 \mathrm{abc}$ & 50.80 \\
T7 & --- & --- & --- & --- & --- & --- & --- & --- \\
Average & 14,738 & 3.83 & 22.71 & --- & 33.10 & 28.45 & -- & 50.30 \\
\hline
\end{tabular}

Averages followed by the same letter in the column do not differ significantly at $5 \%$ probability by the test of Tukey; T1 = single row of cassava (monoculture); $\mathrm{T} 2=$ single row of cassava +1 cowpea; $\mathrm{T} 3=$ double row of cassava (monoculture); $\mathrm{T} 4=$ double row of cassava +1 cowpea; $55=\mathrm{Double}$ row of cassava +2 cowpea; $\mathrm{T} 6=$ Double row of cassava +3 cowpea; $\mathrm{T} 7=$ sole cowpea (monoculture) 
content and, since it is difficult to determine it analytically, in practical terms, it isestimated in the manufacturers from the dry matter (CARVALHO et al., 2007).

The single row treatment of cassava in monoculture (T1) has presented the largest yield $\left(18,265 \mathrm{~kg} \mathrm{ha}^{-1}\right)$, although it has not differed statistically from the double row treatments of cassava +2 rows of cowpea (T5) and double row treatment of cassava +3 rows of cowpea (T6), respectively 17,322 and $15,584 \mathrm{~kg} \mathrm{ha}^{-1}$. In similar works performed in Coimbra (MG), the cassava treatment in single row $(1.0 \times 0.5 \mathrm{~m})$ obtained the largest yield of roots $\left(19,093 \mathrm{~kg} \mathrm{ha}^{-1}\right)$, although it has not differed statistically from the cassava double row treatments in monoculture and cassava double row plus one row of ordinary beans, respectively 17,675 and 16,625 $\mathrm{kg} \mathrm{ha}^{-1}$ (ALBUQUERQUE et al., 2012). Gabriel Filho, Strohhaecker and Fey (2003) and Damasceno, Mattos and Caldas (2001) also obtained yield from roots statistically similar between the sole cassava cultivation in single row $(1 \times 0.6 \mathrm{~m})$ and double row $(2.0 \times 0.5 \times 0.5 \mathrm{~m})$ with cowpea.

Intercropping work of cassava and corn performed by Devide et al. (2009) in Seropédica, in the Brazilian State of Rio de Janeiro, also showed that the corn did not interfere in the commercial yield of tubers of cassava and the harvest of green ears with industry standard, which means the potential for additional income to farmers, with better use of available resources, including justifying the use of irrigation. Including corn, cv. Eldorado, grown in alternating lines of cassava, after the first weeding, did not interfere in commercial yield of roots.

In contradiction to the results, found in studies conducted by Cavalcante, Silva and Araújo (2005) mention that the behavior of intercropped cultures is different from the one presented by sole cultivations.

From the components of yield assessed in the cowpea, the number of pods per plant (NPP), pod length (PL) and the grains yield(YIELD) presented significant differences between the treatments (Table 6), showing that the intercropping with the cassava impacted these characteristics.

As for the yield in the intercropping, the worst performance of cowpea was in the arrangement double rows of cassava with a row of cowpea (Treatment 4) (477 kg ha-1), reduction of $52.82 \%$ compared to the monoculture of the cowpea (Treatment 7), with $903 \mathrm{~kg} \mathrm{ha}^{-1}$ (Table 6).

The other treatments of double row intercropping did not provide significant differences in the yield of the cowpea (Table 6). Alves et al. (2009) also noticed reduction in the yield of different cultivars of cowpea in intercropping with two varieties of cassava.

A variable widely used in the assessment of the cultivation intercropping is the equivalence index of area (EIA). According to Vieira (1984), the intercropping will be efficient when the EIA is over 1.00 and harmful to the yield when below 1.00. The EIA calculated for the arrangements of intercropping studied have ranged from to 1.18 to 1.56 , and the treatment of single row of cassava +1 row of cowpea (T2) have presented the greater EIA (Table 6). These results show advantages for all the treatments intercropped used in this work. In works similar to this one, located in the city of Coimbra (MG), the EIA ranged from 1.28 to 1.54 and the treatment of double row of cassava +3 rows of regular beans have presented the largest index, equal to 1.54 (ALBUQUERQUE et al., 2012).

Table 6 - Average values of the weight of 1,000seeds (WTS), number of pods per plant (NPP), pod length (PL), number of seeds per pod (NSP), yield of grains (YIELD) of cowpea intercropped with cassava and in monoculture and equivalence index of area (EIA) regarding the intercropping. Boa Vista, Roraima state, 2012

\begin{tabular}{lcccccc}
\hline Treatment & WTS $(\mathrm{g})$ & NPP & PL $(\mathrm{cm})$ & NSP & YIELD $\left(\mathrm{kg} \mathrm{ha}^{-1}\right)$ & EIA \\
\hline T1 & --- & --- & --- & --- & --- & --- \\
\hline T2 & 155 & $12.55 \mathrm{c}$ & $14.85 \mathrm{~b}$ & 12.62 & $769 \mathrm{~b}$ & 1.56 \\
\hline T3 & --- & --- & --- & --- & --- & --- \\
\hline T4 & 154 & $14.67 \mathrm{ab}$ & $15.62 \mathrm{a}$ & 13.50 & $477 \mathrm{c}$ & 1.18 \\
T5 & 156 & $13.17 \mathrm{bc}$ & $14.25 \mathrm{c}$ & 13.02 & $751 \mathrm{~b}$ & 1.77 \\
T6 & 155 & $13.00 \mathrm{bc}$ & $13.67 \mathrm{~d}$ & 13.15 & $763 \mathrm{~b}$ & 1.69 \\
T7 & 154 & $15.00 \mathrm{a}$ & $15.15 \mathrm{ab}$ & 13.42 & $903 \mathrm{a}$ & --- \\
\hline Average & 155 & --- & --- & 13.14 & --- & 1.55 \\
\hline Ava
\end{tabular}

Averages followed by the same letter in the column do not differ significantly at $5 \%$ probability by the test of Tukey; T1 = single row of cassava (monoculture); $\mathrm{T} 2=$ single row of cassava +1 beans; $\mathrm{T} 3=$ double row of cassava (monoculture); $\mathrm{T} 4=$ double row of cassava +1 beans; $\mathrm{T} 5=\mathrm{double}$ row of cassava +2 beans; $\mathrm{T} 6=$ double row of cassava +3 beans; $\mathrm{T} 7=$ sole beans (monoculture) 
In works of intercropped systems with the cultivations of cassava and regular beans, Cavalcante, Silva and Araújo (2005) assessing the analysis of the area equivalence index, showed advantages for all the intercropped treatments, since they have reached values over 1.0. Damasceno, Mattos and Caldas (2001), assessing spacial arrangements of cassava in monoculture and intercropped with regular beans and corn in the city of Cruz das Almas (BA), concluded that the EIA of the intercropped treatments have presented values over 1.0.

\section{CONCLUSIONS}

1. The double rows cropping systems of cassava with two and three rows of cowpea allow to obtain equivalent yield to the monoculture of cassava in single rows;

2. The grains yield of the cowpea in single rows (monoculture) is superior to the intercropped treatments;

3. The results of the characteristics of the cassava: fresh weight of shoot, number of roots per plant, root length, root diameter, root dry matter, starch content of the roots and harvest index are not impacted by the intercropped systems;

4. The characteristics of weight of 1,000 seeds and number of seeds per pod of the cowpea are not impacted by the intercropped systems used;

5. All treatments in intercropping systems exhibit a satisfactory area equivalence index, with an average of 1.55.

\section{ACKNOWLEDGEMENTS}

To CNPq and Pro-Reitoria de Pesquisa e PósGraduação (PRPPG)/Universidade Federal de Roraima for financial support under Edital 02/2013 (PRPPG/ PRO-PESQUISA).

\section{REFERENCES}

ALBUQUERQUE, J. A. A. et al. Caracterização morfológica e agronômica de clones de mandioca cultivados em Roraima. Revista Brasileira de Ciência Agrária, v. 4, n. 4, p. 388394, 2009.

ALBUQUERQUE, J. A. A. et al. Cultivo de mandioca e feijão em sistemas consorciados realizado em Coimbra, Minas Gerais. Revista Ciência Agronômica, v. 43, n. 3, p. 532-538, 2012.

ALBUQUERQUE, J. A. A. et al. Interferência de plantas daninhas sobre a produtividade da mandioca (Manihot esculenta). Planta Daninha, v. 26, n. 2, p. 279-289, 2008.
ALBUQUERQUE, J. A. A. et al. Occurrence of weeds in cassava savanna plantations in Roraima. Planta Daninha, v. 32, p. 91-98, 2014.

ALVES, J. M. A. et al. Avaliação agroeconômica da produção de cultivares de feijão-caupi em consórcio com cultivares de mandioca em Roraima. Revista Agro@mbiente On-line, v. 3, n. 1, p. 15-30, 2009.

ANDRADE, M. J. B. et al. Avaliação de sistemas de consórcio de feijão com milho pipoca. Ciência e Agrotecnologia, v. 25, n. 2 , p. $242-250,2001$.

BAUMANN, D. T.; BASTIAANS, L.; KROPFF, M. J. Competition and crop performance in a leek-celery intercropping system. Crop Science, v. 41, n. 3, 764-774, 2001.

BORGES, M. F.; FUKUDA, W. M. G.; ROSSETTI, A. G. Avaliação de variedades de mandioca para o consumo humano. Pesquisa Agropecuária Brasileira, v. 37, n. 11, p. 1559-1565, 2002.

CARVALHO, P. R. N. et al. Avaliação da exatidão, precisão e robustez do método de análise do teor de matéria seca de mandioca (Manihot esculenta, Crantz) por meio da determinação do peso específico (balança hidrostática). Revista Raízes e Amidos Tropicais, v. 3, p. 1-4, 2007.

CAVAlCANTE, F. S.; SILVA, I. F.; ARAÚJO, M. C. S. P. Avaliação da viabilidade do consórcio de mandioca e feijão comum em Latossolo Amarelo no brejo paraibano. Agropecuária Técnica, v. 26, n. 2, p. 93-97, 2005.

COCK, J. H.; EL-SHARKAWAY, M. A. Características fisiológicas para la selección de yuca. In: HERSEY, C. H. (Ed.). Mejoramiento genético de la yuca en América Latina. Cali: CIAT: PNDU, 1991. p. 257-265.

COSTA, A. S.; SILVA, M. B. Sistemas de consórcio milho feijão para a região do vale do rio doce, Minas Gerais. Ciência Agrotecnologia, v. 32, n. 2, p. 663-667, 2008.

DAMASCENO, L. S. P.; MATTOS, P. L. P.; CALDAS, R. C. Arranjos espaciais de mandioca (Manihot esculenta Crantz) em monocultivo e consorciada com feijão (Phaseolus vulgaris L.) e milho (Zea mays L.). Magistra, v. 13, n. 1, p. 21-28, 2001.

DANTAS, A. G. M. et al. Análises bromatológicas de onze cultivares de mandioca. Revista Caatinga, v. 23, n. 3, p. 130136, 2010.

DEVIDE, A. C. P. et al. Produtividade de raízes de mandioca consorciada com milho e caupi em sistema orgânico. Bragantia, v. 68, n. 1, p. 145-153, 2009.

FLESCH, R. D. Efeitos temporais e espaciais no consórcio intercalar de milho e feijão. Pesquisa Agropecuária Brasileira, v. 37, n. 1, p. 51-56, 2002.

FUKUDA, W. M. G. et al. Variedades de mandioca recomendadas para o Estado da Bahia. Bahia Agrícola, v. 7, n, 3, p. 27-30, 2006.

GABRIEL FILHO, A.; STROHHAECKER, L.; FEY, E. Profundidade e espaçamento da mandioca no plantio direto na palha. Ciência Rural, v. 33, n. 3, p. 461-467, 2003. 
GROSSMANN, J.; FREITAS, A. C. Determinação do teor de matéria seca pelo peso específico em raízes de mandioca. Revista Agronômica, v. 14, n. 160/162, p. 75-80, 1950.

INSTITUTO BRASILEIRO DE GEOGRAFIA E ESTATÍSTICA. Levantamento sistemático da produção agrícola. 2014. Disponível em: <ftp://ftp.ibge.gov.br/ producao_agricola/levantamento_sistematico_da_producao_ agricola_2014>. Access em: 02 fev. 2015.

JOHANNS, O.; CONTIERO, R. Efeitos de diferentes períodos de controle e convivência de plantas daninhas com a cultura da mandioca. Revista Ciência Agronômica, v. 37, n. 3, p. 326-331, 2006

MARTINOTTO, F. et al. Sobrevivência e crescimento inicial de espécies arbóreas nativas do cerrado em consórcio com mandioca. Pesquisa Agropecuária Brasileira, v. 47, n. 1, p. 22 29, 2012.

MATTOS, P. L. P. et al. Consorciação da mandioca plantada em fileiras duplas e simples com culturas de ciclo curto. I. mandioca $x$ caupi x milho. Revista Brasileira de Mandioca, v. 18, n. 1, p. $25-30,2005$ a.
MATTOS, P. L. P. et al. Consorciação da mandioca plantada em fileiras duplas e simples com culturas de ciclo curto. II. mandioca x caupi x milho. Revista Brasileira de Mandioca, v. 18 , n. 1 , p. $31-36,2005$ b.

OLIVEIRA, N. T. et al. Caracterização e identificação de clones de mandioca produzidos em Roraima para o consumo in natura. RevistaAgro@mbiente On-line, v. 5, n. 3, p. 188-193, 2011.

OLIVEIRA, N. T. et al. Ácido cianídrico em tecidos de mandioca em função da idade da planta e adubação nitrogenada. Pesquisa Agropecuária Brasileira, v. 47, n. 10, p. 1436-1442, 2012.

SCHONS, A. et al. Arranjos de plantas de mandioca e milho em cultivo solteiro e consorciado: crescimento, desenvolvimento e produtividade. Bragantia, v. 68, n. 1, p. 155-167, 2009.

VIDIGAL FILHO, P. S. Avaliação de cultivares de mandioca na Região Noroeste do Paraná. Bragantia, v. 59, n. 1, p. 69$75,2000$.

VIEIRA, C. Cultivo consorciado de mandioca com feijão. Informe Agropecuário, v. 10, n. 118, p. 13-49, 1984. 